\title{
RESEARCH OF PERIODONTAL STATUS AND TREATMENT NEEDS BY CPITN IN PATIENTS ON HAEMODIALYSIS AND RENAL TRANSPLANTED PATIENTS
}

\author{
Maria Dencheva \\ Department of Image and Oral diagnostics, \\ Faculty of Dental Medicine, Medical University - Sofia
}

\section{SUMMARY:}

The aim of the present study is to estimate the periodontal conditions and treatment needs by CPITN of 150 patients - $45(30 \%)$ on haemodialysis, $45(30 \%)$ renal transplanted patients and $60(40 \%)$ healthy controls, age between 18 and 84 .

The oral health of this population gives rise to a big interest within the past ten years. The interest about oral status is caused not just from age changes, but also from characteristic changes through main illness, dialysis and immunosuppressive drug therapy. Early prevention and diagnostics of oral diseases can improve the health status and graft survival of patients in ESRD.

Key words: CPITN, renal transplantation, haemodialysis, parodontal health, ESRD, .

\section{INTRODUCTION:}

The interaction between oral health and chronic renal disease and renal replacement therapy (4, 5, 9, and 12) are subject of many studies during the last ten years. This scientific interest refers directly to the rising number of ESRD patients and renal transplanted patients worldwide. The situation in Bulgaria is different- the increasing number of patients on haemodialysis compared to the decreasing number of renal transplanted patients (1). The dental activities for optimal oral health during the dialysis before and after transplantation should be synchronized with the professional opinion of nephrologists (2). Untreated periodontal diseases can compromise the immediate posttransplant period (2, 7, and 10). The main reasons of gingivitis in these patients are immunosupression, renal failure, which leads to renal osteodistrophy, and poor oral hygiene $(6,8$, 11, 12 and 13).

The purpose of the present study is to estimate periodontal findings by patients with renal replacement therapy, as well as to determine the relevant treatment needs according to their health status.

Future investigations of maintained oral health in patients, waiting for renal transplant, will increase our knowledge concerning the importance of creating dental protocol, which must be a part of pre and post transplant protocol of each ESRD patient (2).

\section{MATERIALS AND METHODS}

The study protocol was approved by the Bulgarian Council of Medical Science. All the 150 participants have given their confirmed consent after being introduced to the aim of the research by a letter of invitation (Figure 1).

Group HD - patients on haemodialysis, 26 (57, 8\%) female and $19(42,2 \%)$ male from Clinical dialysis center of the "Alexandrovska" hospital and dialysis centers in the towns of Gabrovo, Karlovo, Velingrad and Smolyan.

Group TP- 45 (30\%) renal transplanted patients -25 $(55,6 \%)$ female and $20(44,4 \%)$ male from the nephrology and transplantation clinics of the "Alexandrovska" hospital.

Group K 60 -renal healthy controls, 20 (40\%) male and $40(60 \%)$ female, tested with blood and urine tests and filingin questionnaire about genetic predispositions.

Figure 1. Distribution of the participants in the research

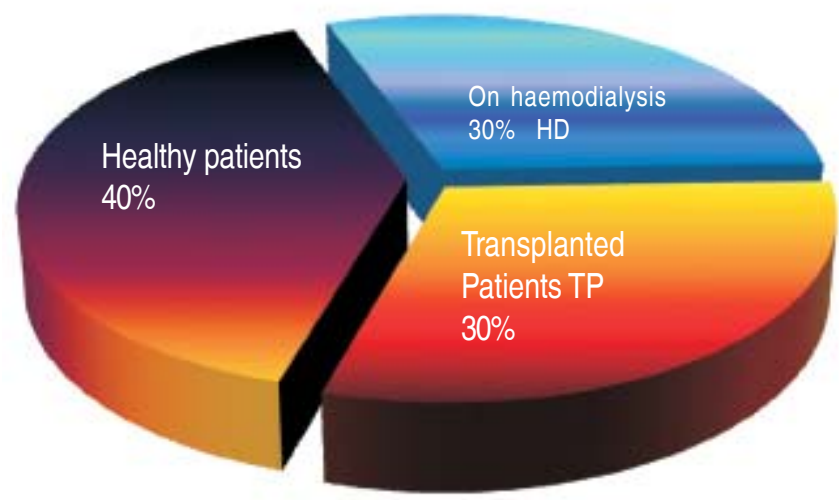

All patients were asked not to brush their teeth before the examination.

The CPITN was a part of a complex focal diagnostics, developed in FDM- Sofia. The CPITN was registered with 
CPITN probe*. Periodontal examination of patients on haemodialysis took place on a day after dialysis, in order to avoid unnecessary and long lasting bleeding during probe.

Renal transplanted patients and healthy controls were checked on the initial examination day.

The Community periodontal index of treatment needs CPITN is an epidemiologic tool, developed by the WHO, for the evaluation of periodontal disease. (3) All teeth were examined, divided into 3 segments on each maxilla and mandible: sextants $1(17,16,15$, and 14), $\mathbf{2}(13,12,11,21$, 22, 23), $\mathbf{3}(24,25,26,27), 4(47,46,45,44), \mathbf{5}(43,42,41,31$, $32,33), 6(34,35,36,37)$. Third molars are not subject to the research, unless they function instead of second molars. Sextants with less than two teeth, indicating for extraction, were labeled with code CPI9.

The worst finding in each sextant is given a code as per the table below. The maximum code for the entire mouth cavity is used for treatment recommendation.

Table 1.

\begin{tabular}{|l|c|}
\hline Findings & Code \\
\hline $\begin{array}{l}\text { Pathologic pockets } \geq 6 \mathrm{~mm} \text { deep , black band on } \\
\text { the probe not visible }\end{array}$ & 4 \\
\hline $\begin{array}{l}\text { Pathologic pockets } \geq 4-5 \mathrm{~mm}, \text { gingival margin } \\
\text { within the black band on the probe }\end{array}$ & 3 \\
\hline $\begin{array}{l}\text { Calculus detected during probing, inexact } \\
\text { orthopedic restorations, but all the black band on } \\
\text { the probe visible }\end{array}$ & 2 \\
\hline Bleeding observed, after gentle probing & 1 \\
\hline Healthy & 0 \\
\hline
\end{tabular}

Table 2.

\begin{tabular}{|c|l|}
\hline $\begin{array}{c}\text { Maximum } \\
\text { score }\end{array}$ & \multicolumn{1}{c|}{ Treatment recommendation } \\
\hline $\mathbf{0}$ & No need for additional treatment \\
\hline $\mathbf{1}$ & Need to improve of personal oral hygiene \\
\hline \multirow{2}{*}{} & $\begin{array}{l}\text { Need for professional tooth cleaning, as well as } \\
\text { improvement of personal oral hygiene }\end{array}$ \\
\cline { 2 - 2 } $\mathbf{3}$ & $\begin{array}{l}\text { Need for professional tooth cleaning, as well as } \\
\text { improvement of personal oral hygiene }\end{array}$ \\
\hline \multirow{4}{*}{$(\mathbf{3})$} & $\begin{array}{l}\text { Need for more complex treatment, subject to } \\
\text { infected tissue removal }\end{array}$ \\
\hline
\end{tabular}

\section{STATISTIC AL ANALYSIS}

All analyses were performed using SPSS 17.0.1. The $\chi^{2}$ tests and the precise Fischer test were used to determine the association between group and CPI. The level of statistical significance was $\mathrm{P}<0.05$.

\section{RESULTS}

\section{General CPI by groups}

Table 3 shows that the frequency of CPI3 and CPI2 in group $\mathrm{K}$ is more significant than groups $\mathrm{HD}$ and TP. CPI2 is significantly higher than CPI3 in group $\mathrm{K}$ in comparison to HD and TP groups. CPI4 is significantly higher than CPI1 in HD and TP groups compared to group $\mathrm{K}$.

Table 3. Frequency distribution of CPI by groups

\begin{tabular}{|lllllllll|}
\hline Groups & Statistics & CPI4 & CPI3 & CPI2 & CPI1 & CPI0 & CPI9 & Total \\
\hline $\mathrm{HD}^{\mathbf{a}}$ & $\mathrm{n}$ & 12 & 13 & 13 & 1 & 0 & 6 & 45 \\
& $\%$ & 26,67 & 28,89 & 28,89 & 2,22 & 0,00 & 13,33 & 100,00 \\
\hline $\mathrm{TP}^{\mathbf{a}}$ & $\mathrm{n}$ & 4 & 11 & 27 & 3 & 0 & 0 & 45 \\
& $\%$ & 8,89 & 24,44 & 60,00 & 6,67 & 0,00 & 0,00 & 100,00 \\
\hline $\mathrm{K}^{\mathbf{b}}$ & $\mathrm{n}$ & 1 & 4 & 43 & 12 & 0 & 0 & 60 \\
& $\%$ & 1,67 & 6,67 & 71,67 & 20,00 & 0,00 & 0,00 & 100,00 \\
\hline Total & $\mathrm{n}$ & 17 & 28 & 83 & 16 & 0 & 6 & 150 \\
& $\%$ & 11,33 & 18,67 & 55,33 & 10,67 & 0,00 & 4,00 & 100,00 \\
\hline
\end{tabular}

* - the same letters indicate a lack of significant difference, while the different letters mark availability of a significant difference $(\mathrm{p}<0.05)$.

- $27 \%$ of HD patients suffer deep parodontal pockets $\geq 6 \mathrm{~mm}$ (CPI 4 ) and $29 \%$ have pockets of up to $5 \mathrm{~mm}$ (CPI3), $29 \%$ CPI2, i.e. sub and/or supragingival calculus, in precise orthopedic restorations(bridges, crowns) and fillings. The frequency of sextants without a minimum of two teeth CPI9 was higher compared to groups $\mathrm{K}$ and $\mathrm{TP}$. The need for

* A specially designed lightweight CPI probe with a $0,5 \mathrm{~mm}$ ball tip, with a black band between 3,5 and $5 \mathrm{~mm}$ and marks on 8,5 and $11,5 \mathrm{~mm}$ from the ball tip. 
complex and specialized treatment (TN 3) in HD patients was higher than of $\mathrm{K}$. Therefore, in group HD the treatment needs are the most complex ones.

- $60 \%$ from group TP have gingival pockets of up to $3,5 \mathrm{~mm}$ and sub-and/or supragingival calculus. The percentage of patients with code CPI 3 is also high, shallow pockets of up to $5 \mathrm{~mm}$ and it requires the above- mentioned treatment activities.

Most patients in group K (71\%) were with CPI2.

- In none of the three groups were we able to find a patient with healthy parodont in all sextants CPI0.

\section{CONCLUSIONS:}

The parodontal therapy is a very important part of complex focal sanitation in patients, receiving renal replacement therapy, including haemodialysis or renal transplantation.

In group HD it is determined that the heaviest periodontal issues with full symptomatic, which requires complex treatment (TN 3).

Patients on haemodialysis are future renal recipients, i.e. dental sanitation for their group is imperative. The other tendency in the group is the higher rate of tooth loss (19\%). In this case, the logical questions are: Are this tooth losses through orthopedic restoration with dentures or bridges and crowns optimally reconstructs and is their masticatory function effective?

The purpose in group TP is early prophylaxis of active focal infections in first three post-transplanted months (2, 6, and 8) when the biggest danger for graft rejection exists.

The periodontal status of this group shows better indexes compared with these of group HD. The main treatment needs are oral hygiene instructions and professional removal of dental plaque and calculus CPI 2.

We also detected a high level $(71 \%)$ of CPI 2 in group $\mathrm{K}$ - health controls. Although it was not the aim of the

\section{REFERENCES:}

1. Data from www.bultransplant.bg

2. Джемилева T, Т. Болярова. Гингивално разрастване при системна терапия с калциеви антагонисти, имуносупресори и хидантоини. Ацер, 2007, 118. (in Bulgarian)

3. Ainamo J, Barnes D, Beagrie G, Cutress T, Martin J, Sardo-Infirri J.. Development of the World Health Organization (WHO) Community Periodontal Index of Treatment Needs (CPITN). International Dental Journal. 1982 Sep;32(3):281-291. [PubMed]

4. Borawski J, M WilczynskaBorawska, Stokowska W, Mysliwiec M. The periodontal status of pre-dialysis chronic kidney disease and maintenance dialysis patients. Nephrol Dial Transplant 2007 Feb;22(2):457-464. [doi: 10.1093/ ndt/gfl676 CrossRef] [PubMed]

5. Graig RG, Kotanko P, Kamer AR, Levin NW. Periodontal diseases- a modifiable source of systemic inflammation for the end-stage renal disease patient on hemodialysis therapy. Nephrol Dial Transplant 2007 Feb;22(2):312-315. [doi: 10.1093/ndt/gfl604 CrossRef] [PubMed]

6. Niederhagen B, Wolff M, Appel T, von Lindern JJ, Berge S. Location and sanitation of dental foci in liver transplantation. Transpl Int. 2003 Mar;16(3):173-178. [DOI: 10.1111/j.14322277.2003.tb00282.x CrossRef] [PubMed]

7. Pernu HE, Pernu LM, Huttunen KR, Nieminen PA, Knuuttila ML. Gingival overgrowth among renal transplant recipients related to immunosuppressive medication and possible local background factors. J Periodontol. 1992 Jun;63(6):54853. [PubMed]

8. Rustemeyer J, Black M, Bremerich A. Stellenwert der dentalen und parodontalen Fokusssanierung vor Organtransplantationen und Herzklappenersatz. Transplantazionsmedizin $2006 ; 18: 24$.

9. Sowell Sb. Dental care for patients with renal failure and renal transplants. $J$
Am Dent Assoc. 1982 Feb;104(2):171-7. [PubMed]

10. Thomason JM, Seymour RA. Rice N. The prevalence and severity of cyclosporin and nifedipine-induced gingival overgrowth. J Clin Periodontol 1993 Jan;20(1):37-40. [PubMed]

11. Toivonen HJ. Anaesthesia for patients with a transplanted organ. Acta Anaesthesiol Scandinavica 2000 Aug;44(7):812-833. [DOI: 10.1034/j.13996576.2000.440708.x CrossRef] [PubMed]

12. Tong DC, Walker RJ. Antibiotic prophylaxis in dialysis patients undergoing invasive dental treatment. Nephrology 2004 Jun;9(3):167-170. [DOI: 10.1111/j.14401797.2004.00245.x CrossRef] [PubMed]

13. Villacian JS, Paya CV. Prevention of infections in solid organ transplant recipients. Transplant Infectious Disease 1999 Mar;1(1):50-64. [DOI: 10.1034/ j.1399-3062.1999.10106.x CrossRef] [PubMed]

\author{
Address for correspondence: \\ Dr. Maria Dencheva, $\mathrm{PhD}$ \\ Department of Image and Oral diagnostics, \\ Faculty of Dental Medicine, Medical University - Sofia \\ 1, G. Sofiiski str., 1000 Sofia, Bulgaria \\ E-mail: jivena@abv.bg
}

